\title{
BIOPROSPECTING OF MARINE SPONGE (CALLYSPONGIA DIFFUSA) FOR ANTIBACTERIAL COMPOUND
}

\author{
BINDU D ${ }^{1}$, VINOTH KUMAR T ${ }^{1}$, GEETHARAMANI ${ }^{2 *}$
}

${ }^{1}$ Department of Microbiology, School of Biological Sciences, CMS College of Science and Commerce, Coimbatore, TamilNadu, India. ${ }^{2}$ PG and Research Department of Microbiology, Dr. N. G. P. Arts and Science College, Coimbatore, TamilNadu, India. . Email: geethavinoth@gmail.com

Received: 20 May 2017, Revised and Accepted: 05 October 2017

\section{ABSTRACT}

Objective: Marine sponges are a rich source of new antimicrobial drugs. The present study was aimed to evaluate the antibacterial activity of the marine sponge (Callyspongia diffusa) against human pathogenic bacteria and to analyze the presence of bioactive compounds in the sponge.

Methods: Antibacterial activity of the marine sponge $C$. diffuser was examined using petroleum ether, chloroform, n-butanol, methanol, ethanol, and water as solvents and tested against human pathogenic bacteria such as Esherichia coli, Pseudomonas aeruginosa, and Staphylococcus aureus by agar well diffusion method. Zoochemical analysis was performed to screen for the presence of secondary metabolites. Bioactive compounds were purified by thin layer chromatography (TLC) and were identified by gas chromatography-mass spectrometry (GC-MS) analysis.

Results: The results obtained show that the sponge extracts had significant antibacterial activity against the tested strains. The methanol extract was found to be the most effective and exhibited the highest potency against all pathogens tested. Zoochemical analysis revealed the presence of alkaloids, terpenoids, and sterols. In TLC, spots corresponding to a Rf value of 0.67 were found to possess antibacterial activity against the test bacteria. GC-MS chromatogram showed seven major peaks at retention time of $12.69,13.81,24.21,24.65,28.01,28.93,30.87$ minutes. The mass of the compounds and fragments were matched with the National Institute of Standard and Technology (NIST) database for identification of probable compounds present in the sample. GC-MS analysis revealed the presence of bioactive compounds in the sponge.

Conclusion: This study confirms the marine natural species provides an excellent source of bioactive metabolites that can exploit to develop novel and potential therapeutic agents.

Keywords: Callyspongia diffusa, Solvent extraction, Antibacterial activity, Thin layer chromatography, Gas chromatography-mass spectrometry.

(C) 2018 The Authors. Published by Innovare Academic Sciences Pvt Ltd. This is an open access article under the CC BY license (http://creativecommons. org/licenses/by/4. 0/) DOI: http://dx.doi.org/10.22159/ajpcr.2018.v11i1.20078

\section{INTRODUCTION}

Sponges belong to the phylum Porifera, and they are ancient metazoans that have existed since 700-800 million years. They are abundantly present not only in the tropical oceans but also occur in temperate waters and even in fresh water [1]. They are simple multicellular invertebrates, and they are attached to solid substrates in benthic habitats [2]. The sponges are of three classes, namely, the Calcarea ( 5 orders and 24 families), Demospongiae (15 orders and 92 families), and Hexactinellida ( 6 orders and 20 families). About 15,000 species of sponges have been described so far [3].

Marine sponges are rich sources of pharmacological compounds [4]. Studies show that secondary metabolites of sponges play an important role in their survival in the marine water $[5,6]$. These secondary metabolites have interesting biomedical, pharmaceutical, and biotechnological applications [7]. These bioactive compounds are attributed to their antimicrobial, antiviral, antitumor, and general cytotoxic properties [8]. Porifera is the most important phylum, as it provides a number of natural products, especially novel pharmacologically active compounds [9].

Bioactive compounds from marine sponges have extensive application for the treatment of many diseases. Several molecules isolated from various sponges are involved in the advanced stage of clinical trials. In this study, we tested the organic extracts of marine sponge (Callyspongia sp.) for antibacterial activity against three strains of pathogenic bacteria followed by gas chromatography-mass spectrometry (GC-MS) analysis to separate and identify the major chemical compounds present in the sample.

\section{MATERIALS AND METHODS}

\section{Collection of marine sponge}

The sponge was collected from the Krusadai Island, Gulf of Mannar, Ramanathapuram District, Tamil Nadu, India. It is $3 \mathrm{~km}$ from Pamban and $500 \mathrm{~m}$ from Kundugal point (Lat $9^{\circ} 15^{\prime} 00^{\prime \prime} \mathrm{N}$, Long $79^{\circ} 13^{\prime} 25^{\prime \prime} \mathrm{E}$ ). Sponges were collected by scuba diving at a depth of 5-10 m. A part of the specimen has been deposited in the Microbiology Research laboratory of Dr. N. G. P. Arts and Science College for records.

\section{Identification of sponge}

The sponge was identified as Callyspongia diffusa by Dr. R. Saravanan, Scientist, Central Marine Fisheries Research Institute, Mandapam Coast based on the skeletal characteristics (size and shape of the spicules), and external morphology. The color of its exterior was yellowish to purplish. Its body has small protrusions, cavities, and branches.

- Kingdom: Animalia

- Phylum: Porifera

- Class: Demospongiae

- Order: Haplosclerida

- Family: Callyspongidae

- Genus: Callyspongia

- Species: C. diffusa

- Generic name: Sponges

- Common name: Callyspongid sponge

\section{Extraction of bioactive compounds from sponge}

The sponge was rinsed thoroughly with sterile seawater to remove algae or if any bacteria present on the surface of the sponge. The sponge was then cut into small pieces of about $5 \mathrm{~cm}$ and then homogenized 
by crushing in a mortar and pestle [10]. The homogenized sponge was subjected to sequential solvent extraction employing solvents of varying polarity, namely, petroleum ether, chloroform, n-butanol, methanol, ethanol, and water. The solvents employed for extraction were of analytical grade purchased from HiMedia Laboratory, Mumbai, India. The extraction was carried out using a Soxhlet apparatus for $48 \mathrm{hrs}$ [11]. After extraction, the extracts were concentrated in a Rotavapor (Equitron) and the concentrated extracts were collected in airtight glass screw cap tubes and preserved at $4{ }^{\circ} \mathrm{C}$ for further use [12].

\section{Collection of bacterial culture}

The pathogenic pure cultures of Escherichia coli, Pseudomonas aeruginosa, and Staphylococcus aureus were obtained from Jansons MRI Diagnostic Pvt. Ltd., Erode, Tamil Nadu. The pure cultures were then subcultured on nutrient agar slants and preserved at $-4^{\circ} \mathrm{C}$ until further use.

\section{Determination of antibacterial activity of the extracts}

The antibacterial activity of the extracts of $C$. diffusa was determined by the standard agar well diffusion assay on Mueller-Hinton agar (HiMedia) [13,14]. The concentrated extracts were dissolved in dimethyl sulfoxide (DMSO) [15]. Wells of $8 \mathrm{~mm}$ diameter were punched using sterilized cork borer. $1 \mathrm{ml}$ exponential phase culture of the test bacteria corresponding to $0.5 \mathrm{ml}$ McFarland opacity was swabbed with a sterile cotton on the surface of the medium. $50 \mu \mathrm{l}$ of each extract in DMSO $(500 \mu \mathrm{g} / \mathrm{ml})$ was dispensed into different wells. DMSO was maintained as a control for each test organism. The plates were incubated at $37^{\circ} \mathrm{C}$. Areas of inhibited microbial growth were observed as a clear zone around the well after $24 \mathrm{hrs}$. Antimicrobial activity was measured with the help of a scale, and the diameter of inhibition zone was recorded. The tests were done in triplicates.

\section{Statistical analysis}

The values of antibacterial activity of the extracts of sponge $C$. diffusa are expressed as the mean \pm standard deviation (SD) $(n=3)$ [Table 1].

\section{Zoochemical analysis}

Zoohemical analysis was performed on extracts of $C$. diffusa $[16,17]$.

\section{Test for alkaloids}

One ml of the extract was treated with Mayer's reagent. Yellow color precipitate formation indicates the presence of alkaloids.

\section{Test for terpenoids}

The extract was dissolved in an equal amount of chloroform and evaporated to dryness. Then, concentrated sulfuric acid is added and heated for about 2 minutes. Gray color formation indicates the presence of terpenoids.

\section{Test for flavonoids}

The extract was mixed with a few fragments of magnesium ribbon and to this concentrated hydrochloric acid was added. Pink color formation indicates the presence of flavonoids.

\section{Test for sterols}

The crude extract was mixed with chloroform and concentrated sulfuric acid. Red color formation indicates the presence of sterols. [Table 2]

\section{Thin layer chromatography (TLC)}

TLC aluminum sheets coated with silica gel were used for the TLC study. The methanol extract suspended in water was then spotted on the TLC plate using a capillary tube. The plates were then developed in closed glass chambers saturated with the developing solvents (petroleum ether:hexane:Chloroform - 60:20:20). After a plate had run, it was removed from the developing chamber and dried in air. The separated compounds were then visualized using long wavelength ultraviolet light. The components separated were then scraped from the plates and collected in Eppendoff® microfuge tubes.
Determination of antibacterial activity of the separated compounds The compounds separated by TLC were then extracted with methanol. The extract was then dried, and $50 \mu \mathrm{g}$ of the extracted compound was reconstituted in $50 \mu$ l of water. Wells of $8 \mathrm{~mm}$ diameter were punched using sterilized cork borer. $1 \mathrm{ml}$ exponential phase culture of the test bacteria corresponding to $0.5 \mathrm{ml} \mathrm{McFarland} \mathrm{opacity} \mathrm{was} \mathrm{swabbed} \mathrm{with} \mathrm{a} \mathrm{sterile} \mathrm{cotton}$ on the surface of the medium. The suspension of different concentration 25 $\mu \mathrm{l}, 50 \mu \mathrm{l}$, and $100 \mu \mathrm{l}$ was then loaded into the wells on Muller-Hinton agar seeded with the bacterial test culture. Solvent control and the standard antibiotic disc ciprofloxacin $(5 \mathrm{mcg}$ ) were maintained as a control for each test organism. The plates were incubated at $37^{\circ} \mathrm{C}$ for $24 \mathrm{hrs}$ to determine the antibacterial activity of the separated compounds. Antimicrobial activity was measured using a scale, and the diameter of inhibition zone was recorded. The tests were carried out in triplicates [Table 3].

\section{GC-MS analysis}

The GC-MS used in the present study was Perkin Elmer made with GC model as Clarus 680 and Mass Spectrometer model as Clarus 680 (EI). The instrumental acquisition parameter was as follows. Oven: Initial temperature $60^{\circ} \mathrm{C}$ for 2 minutes, ramp $10^{\circ} \mathrm{C} /$ minutes to $300^{\circ} \mathrm{C}$, hold 6 minutes, total run time $=32.0$ minutes. Carrier gas was Helium and the column was Elite 5MS. The mass condition (EI) was kept as follows. Solvent delay $=2.00$ minutes, transfer temperature $=230^{\circ} \mathrm{C}$, source temperature $=230^{\circ} \mathrm{C}$, and scan $=50-600 \mathrm{Da}$.

\section{Identification of components}

The chromatograph showing peaks corresponding to different compounds were obtained and interpreted. Interpretation was carried out using the database of National Institute Standard and Technology (NIST). The spectrum of the unknown components was compared with the spectrum of known components stored in the NIST library. The name, molecular weight, and molecular formula of the components of the test materials were ascertained [Table 4].

\section{RESULTS AND DISCUSSION}

The trend of antibacterial activities of the extracts of $C$. diffusa against human pathogenic bacteria indicates that the solvent extracts of $C$. diffusa possess antibacterial activity against all the test bacteria such as E. coli, $P$. aeruginosa, and $S$. aureus and the results are expressed as mean $\pm \mathrm{SD}$ $(\mathrm{n}=3)$. A maximum diameter zone of inhibition $(19.33 \pm 0.57 \mathrm{~mm})$ for $E$. coli was observed with methanol extract. Maximum diameter zone of inhibition $(20.00 \pm 1.00 \mathrm{~mm})$ for P. aeruginosa was observed with petroleum ether extract. A maximum diameter zone of inhibition $(16.66 \pm 1.52 \mathrm{~mm})$ for $S$. aureus was observed with methanol extract. There was no zone of inhibition for the control DMSO against all the test bacteria. The result indicates that the solvent extracts exhibited greater antibacterial activity.

Results of Zoochemical analysis revealed the presence of alkaloids, terpenoids, and sterols. It was observed that alkaloids were detected in the methanol, ethanol, petroleum ether, chloroform, and n-butanol extracts. Terpenoids were detected in the methanol, ethanol, petroleum

Table 1: Antibacterial activities of extracts of $C$. diffusa

\begin{tabular}{llll}
\hline \multicolumn{4}{l}{ Zone of inhibition $(\mathbf{m m})$} \\
\hline $\begin{array}{llll}\text { Extracts } \\
\mathbf{5 0 0} \boldsymbol{\mu g} / \mathbf{m l})\end{array}$ & Bacteria & & \\
\cline { 2 - 4 } & E. coli & S. aureus & P. aeruginosa \\
\hline Methanol & $19.33 \pm 0.57$ & $16.66 \pm 1.00$ & $19.66 \pm 0.57$ \\
N-Butanol & $17.33 \pm 0.57$ & $15.00 \pm 1.52$ & $18.33 \pm 1.52$ \\
Ethanol & $16.00 \pm 1.00$ & $15.33 \pm 0.57$ & $17.00 \pm 1.00$ \\
Chloroform & Nil & $12.66 \pm 1.52$ & $11.66 \pm 1.52$ \\
Petroleum ether & $18.66 \pm 1.52$ & $16.33 \pm 0.57$ & $20.00 \pm 1.00$ \\
Water & Nil & Nil & Nil \\
DMSO & Nil & Nil & Nil \\
\hline VMl
\end{tabular}

Values are expressed as mean \pm standard deviation of the three replicates.

C. diffusa: Callyspongia diffusa, E. coli: Esherichia coli, S. aureus: Staphylococcus aureus, P. aeruginosa: Pseudomonas aeruginosa, DMSO: Dimethyl sulfoxide 
Table 2: Zoochemical analysis of extracts of $C$. diffusa

\begin{tabular}{|c|c|c|c|c|c|}
\hline Sponge & Extract & Alkaloids & Terpenoids & Flavonoids & Sterols \\
\hline \multirow[t]{6}{*}{ C. diffusa } & Methanol & + & + & - & - \\
\hline & N-Butanol & + & + & - & - \\
\hline & Ethanol & + & - & - & + \\
\hline & Chloroform & + & + & - & + \\
\hline & Petroleum ether & + & + & - & + \\
\hline & Water & - & - & - & - \\
\hline
\end{tabular}

C. diffusa: Callyspongia diffusa

Table 3: Antibacterial activities of TLC scrapings of $C$. diffusa

\begin{tabular}{|c|c|c|c|c|c|}
\hline \multirow[t]{2}{*}{ Name of the pathogen } & \multicolumn{5}{|c|}{ Zone of inhibition } \\
\hline & $25 \mu l$ & $50 \mu l$ & $100 \mu l$ & Ciprofloxacin disc (5 mcg) & N-butanol \\
\hline E.coli & $12.00 \pm 1 \mathrm{~mm}$ & $18.00 \pm 1 \mathrm{~mm}$ & $22.33 \pm 0.57 \mathrm{~mm}$ & Nil & Nil \\
\hline P. aeruginosa & $16.66 \pm 1.52 \mathrm{~mm}$ & $20.00 \pm 2 \mathrm{~mm}$ & $23.66 \pm 1.52 \mathrm{~mm}$ & $24.33 \pm 0.57 \mathrm{~mm}$ & Nil \\
\hline S. aureus & $16.33 \pm 0.57 \mathrm{~mm}$ & $21.00 \pm 1 \mathrm{~mm}$ & $23.00 \pm 1 \mathrm{~mm}$ & $\mathrm{Nil}$ & Nil \\
\hline
\end{tabular}

Values are expressed as mean \pm standard deviation of the three replicates. E. coli: Esherichia coli, S. aureus: Staphylococcus aureus, P. aeruginosa: Pseudomonas aeruginosa, C. diffusa: Callyspongia diffusa, TLC: Thin layer chromatography

Table 4: GC-MS analysis

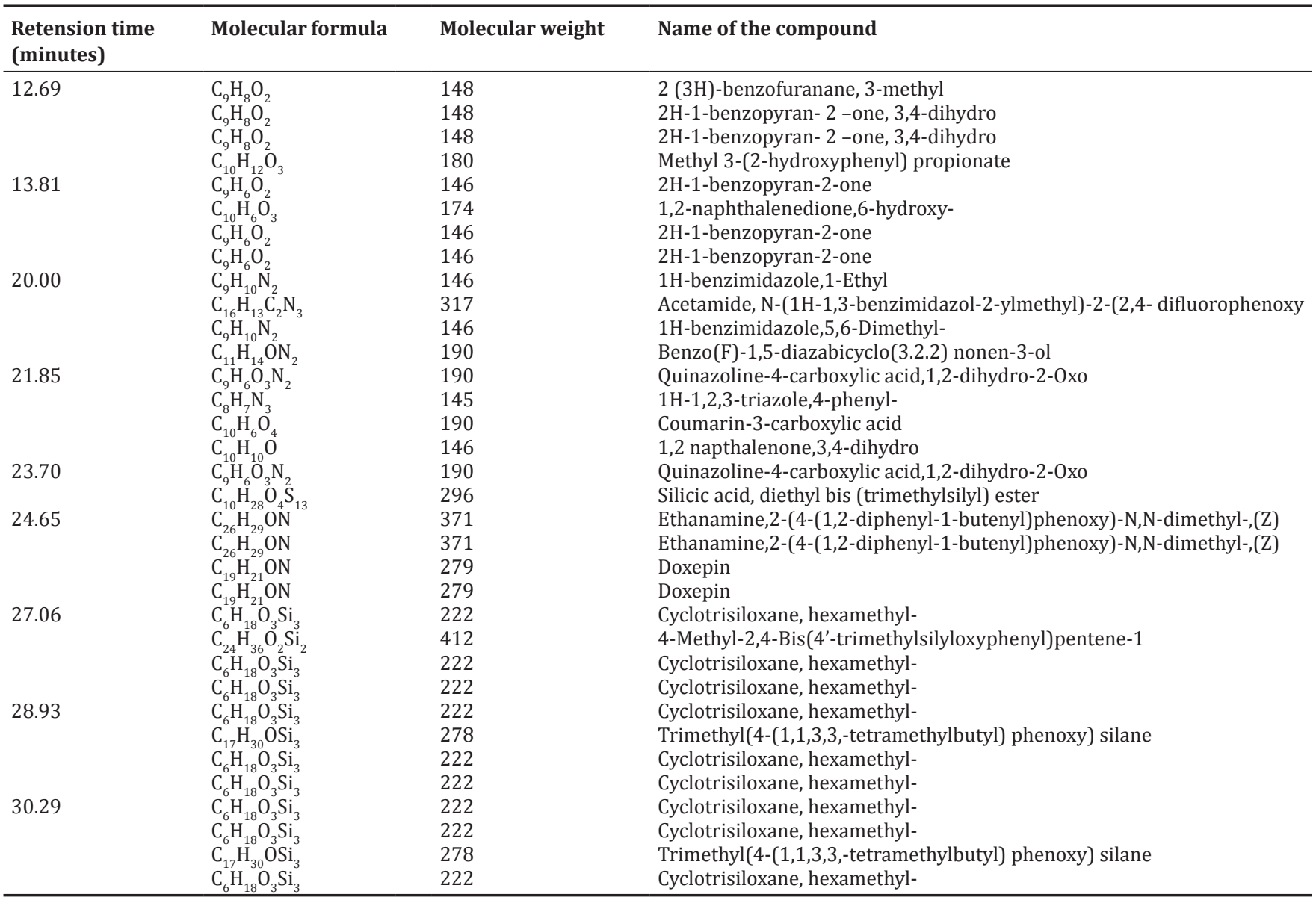

GC-MS: Gas chromatograph-mass spectroscopy

ether, and chloroform extracts. Sterols were detected in ethanol, chloroform, and petroleum ether extracts. None of the extracts tested had shown the presence of flavonoids.

In TLC, spots were visualized under ultraviolet light. Spots corresponding to a $\mathrm{Rf}$ value of 0.67 were found to possess antibacterial activity against the test bacteria. The standard antibiotic (ciprofloxacin) was effective against $P$. aeruginosa but it was resistant to E. coli and
S. aureus. The solvent control showed no zone of inhibition against all the test bacteria.

The GC-MS analysis of potential extract revealed the occurrence of different compounds corresponding to the peaks obtained at different retention times including $2(3 \mathrm{H})$-benzofuranane, 3-methyl, 2H-1-benzopyran- 2 -one,3,4-dihydro, methyl 3-(2-hydroxyphenyl) propionate, 2H-1-benzopyran-2-one, 1,2-naphthalenedione,6-hydroxy, 
1H-benzimidazole, 1-ethyl, acetamide, N-(1H-1,3-benzimidazol-2ylmethyl)-2-(2,4-difluorophenoxy, 1H-benzimidazole,5,6-dimethyl, benzo(F)-1,5-diazabicyclo(3.2.2) nonen-3-ol, quinazoline-4-carboxylic acid,1,2-dihydro-2-0xo, 1H-1,2,3-triazole,4-phenyl, coumarin-3carboxylic acid, 1,2 napthalenone,3,4-dihydro, Silicic acid, diethyl bis (trimethylsilyl) ester, ethanamine,2-(4-(1,2-diphenyl-1-butenyl) phenoxy)-N,N-dimethyl-,(Z), doxepin, cyclotrisiloxane, hexamethyl, 4-methyl-2,4-Bis(4'-trimethylsilyloxyphenyl) pentene-1,trimethyl(4(1,1,3,3,-tetramethylbutyl) phenoxy) silane.

\section{DISCUSSION}

Drug discovery has become a very important field of study within the past few decades. With the rate of drug resistance by pathogenic microbes that cause human infection, it has become increasingly important to investigate natural products for novel antimicrobial compounds. Marine organisms consist of a valuable source of new compounds. In this study, the extracts of the sponge $C$. diffusa showed effective antibacterial activity against $E$. coli, P. aeruginosa, and S. aureus.

Zoochemical analysis revealed the presence of alkaloids, terpenoids, and sterols in the sponge subjected to study. Alkaloids are nitrogenous organic compounds which have a wide range of applications in pharmacology and cosmetic industries [18]. The marine sponge hexane extract of a A. Globe stellata is reported to have antioxidant properties due to the presence of phenolic and flavonoids content in the sponge [19]. It is also reported that sponge associated bacterial extracts have cytotoxicity effect on MOLT 4 cell lines through apoptosis [20].

The bioactive compounds were confirmed by GC-MS analysis. Although most of the compounds isolated in the present study have been known for various biological activities, the compound 2H-1-Benzopyran-2one exhibit wide range of biological activities such as antimicrobial, antiviral, antidiabetic, anticancer activity, antioxidant, antiparasitic, anti-helminthic, antiproliferative, anticonvulsant, anti-inflammatory, and antihypertensive activities. [21]. Cyclotrisiloxane, hexamethyl has been demonstrated to exhibit significant pharmacological effects such as antimicrobial, anti-inflammatory, antioxidant etc. [22]. Cyclohexasiloxane dodecamethyl isolated from marine sponge $S$. pumila is reported to have many industrial applications and in household care products [23]. 1,2 Napthhalenedione-6-hydroxy has biological activities such as Larvicidal, antibacterial, antifungal, antiviral, insecticidal, anti-inflammatory, and antipyretic activity. [24]. By isolating and identifying these bioactive compounds, new drugs can be formulated to treat different diseases.

\section{CONCLUSION}

The present study indicates the presence of an active antibacterial compound in marine sponge $C$. diffusa. The results support that sponge C. diffusa could be a valuable source of novel substances for future drug discovery. A detailed investigation with the objective of isolating biologically active molecules along with the search for novel compounds is currently under study.

\section{REFERENCES}

1. Radjasa OK, Sabdono A, Zocchi E. Richness of secondary metabolite producing marine bacteria associated with sponge Haliclona sp. Int J Pharm 2007;3:275-79.
2. Lee YK, Lee JH, Lee HK. Microbial symbiosis in marine sponges. J Microbiol 2001;39:254-64.

3. Fieseler L, Horn M, Wagner M, Hentschel U. Discovery of the novel candidate phylum "poribacteria" in marine sponges. Appl Environ Microbiol 2004;70:3724-32.

4. Azevedo LG, Peraza GG, Lerner C, Soares A, Murcia N, MuccilloBaisch AL. Investigation of the anti-inflammatory and analgesic effects from an extract of Aplysina caissara, a marine sponge. Fundam Clin Pharmacol 2008;22:549-56.

5. Thakur NL, Muller W. Biotechnological potential of marine sponges. Curr Sci 2004;86:1506-12.

6. Hochmuth T, Niederkrüger H, Gernert C, Siegl A, Taudien S, Platzer M, et al. Linking chemical and microbial diversity in marine sponges: Possible role for poribacteria as producers of methyl-branched fatty acids. Chem Bio Chem 2010;11:2572-78.

7. Taylor MW, Radax R, Steger D, Wagner M. Sponge-associated microorganisms: Evolution, ecology, and biotechnological potential. Microbiol Mol Biol Rev 2007;71:295-347.

8. Wang G. Diversity and biotechnological potential of the spongeassociated microbial consortia. J Ind Microbiol Biotechnol 2006;33:545-51.

9. Gunasekera AS, Sfanos KS, Harmody DK, Pomponi SA, McCarthy PJ, Lopez JV. HBMMD: An enhanced database of the microorganisms associated with deeper water marine invertebrates. Appl Microbiol Biotechnol 2005;66:373-76.

10. Warad VB, Habbu P. Antimicrobial activity of Callyspongia diffusa (Marine sponge) associated endophytic bacterial strains. Int J Pharm Pharm Sci 2017;9:90-6.

11. Naz S, Jabeen S, Ilyas S, Manzoor F, Aslam F, Ali A. Antibacterial activity of Curcuma longa varieties against different strains of bacteria. Pak J Bot 2010;42:455-62.

12. Suresh M, Arularasan S, Kumaran NS. Screening on antimicrobial activity of Marine gastropods Babylonia zeylanica and Harpa conoidalis from mudasalodai, Southeast coast of India. Int J Pharm Pharm Sci 2012;4:552-6.

13. Murray PR, Baron EJ, Pfaller MA, Tenover FC, Yolken HR. Manual of Clinical Microbiology. $6^{\text {th }}$ ed. Washington, DC: ASM Press; 1995. p. $15-8$.

14. Olurinola PF. A Laboratory Manual of Pharmaceutical Microbiology. Idu, Abuja, Nigeria: Gumming Publishing Company; 1996. p. 69-105.

15. Nair R, Kalariya T, Chanda S. Antibacterial activity of some selected Indian medicinal flora. Turk J Biol 2005;29:41-7.

16. Harborne JB. Phytochemical Methods. London: Chapman and Hall Ltd.; 1973. p. 49-188.

17. Trease GE, Evans WC. Pharmacognosy. $13^{\text {rd }}$ ed. London: Balliere Tindall; 1989. p. 176-80.

18. Available from: http://www.dermaviduals.com/cms/upload/publikationen english/k1-12-14-Alkaloide-engl.pdf

19. Sugapriya M, Sudarsanam D. Free radical screening activity of marine sponge Aurora globostellata. Asian J Pharm Clin Res 2016;9:210-2.

20. Karwati A, Nomura J, Ramli N, Wahyudi AT. Cytotoxicity of crude extract from sponge associated bacteria against MOLT4 leukemia cell lines through apoptosis. Int J Pharm Pharm Sci 2015;7:246-9.

21. Pangal A, Gazge M, Mane V, Shaikh J. Various pharmacological aspects of coumarin derivatives: A review. Int $\mathrm{J}$ Pharm Biosci 2013;2:168-94

22. Patil US, Deshmukh OS. GC-MS analysis of phytochemicals in the aqueous extract of Cyclea peltata. (Lam). Int J Sci Res 2015;4:350-51.

23. Thambidurai Y, Sudarshanam D, Habeek SK, Kizhakudan JK. Screening of bioactive compounds from marine sponges collected from Kovalam, Chennai. Asian J Pharm Clin Res 2017;10:231-36.

24. Babula P, Adam V, Havel L, Kizek R. Naphthoquinones and their pharmacological properties. Ceska Slov Farm 2007;56:114-20. 